\title{
Trash or Treasure? \\ Pop Fiction in Academic and Research Libraries
}

\section{Robert G. Sewell}

Since the 1960s, there has been a growing interest in popular culture as a phenomenon worthy of academic study. Undergraduate and graduate courses and research publications in this area have proliferated. This activity requires libraries to collect research and teaching materials that are often considered unsuitable, popular trash. Because of its format, pop fiction is the most congenial of all the popular culture materials to collect, but it presents many problems. Some libraries have established separate or special collections for pop fiction; others have collected pop fiction without specific academic programs and integrated it into general collections. Usually, libraries have reacted according to local demands for pop fiction. It is clear, however, that coordination and planning on regional and national levels are needed in the development of pop fiction resources.

n incident occurred several years ago at a major academic library which demonstrates some of the problems related to building research collections in new areas, in this case the area of popular culture. An extensive collection of novels on which films had been based was donated to the library. The books were to be kept intact as a special collection in the rare book facility. The collection was an important resource for cinema studies and English. Somehow the original concept of the collection was lost and the books were processed according to normal gift procedures. When the titles were searched, some were marked as duplicates. Furthermore, a large percentage of the books were shabby, yellowlooking paperbacks of popular fictionmysteries, westerns, and science fiction. The whole assortment seemed an unimpressive addition to the library's prestigious research collections. A few books were added to the general stacks, but the majority were either thrown away or put up for sale at a semi-annual book sale.

This was an unhappy event in the history of the library. The benefactor was furious over the loss of a collection which he had assembled with great care for many years. The library staff was embarrassed and apologetic, although some felt their actions were not totally unjustified. Why should pop fiction be collected by academic and research libraries, let alone be placed side-by-side with books of fine printing and illustrated manuscripts?

This article explores popular culture studies in higher education and how libraries are responding to the needs of popular culture specialists. Special focus will be given to pop fiction in book format, the most congenial to present-day libraries.

\section{POPULAR CULTURE STUDIES}

In order to understand the resource needs for popular culture studies, we. must begin by assessing the field and its role in higher education. A statement by

Robert G. Sewell is assistant to the director of library collections, University of Illinois at Urbana-Champaign, Urbana, Illinois 61801. 
the Popular Culture Association, which was founded in 1969, describes the purpose of the association and defines popular culture studies:

The Popular Culture Association was founded to study thoroughly and seriously those productions, both artistic and commercial, designed for mass consumption. The founders were convinced that this vast body of material encompassed in print, film, television, comics, advertising, and graphics reflects the values, convictions, and patterns of thought and feeling generally dispersed through and approved by American society. ${ }^{1}$

What is important in this statement for our concerns is that materials designed for mass consumption are analyzed to discover patterns of thought and feeling generally dispersed through and approved by American society. The very objects surrounding us in our daily lives are important research materials. They are primary sources for understanding society's values and sensibilities. In this way, what some consider the commercialized trash of mass society takes on significance for the popular culture researcher such as the social historian, English professor, or sociologist.

The main focus of this article will be on pop fiction: genre or formula fictionscience fiction, the western, the mystery or detective novel, the romance, even the super-hero comic book-as well as its antecedents, the "broadsheets" or newspaper "supplements" of the 1840 s and the dime and nickel novels published in the latter half of the nineteenth and early twentieth centuries. The staples of nineteenth century pop fiction were, as today, romance, violence, and adventure. The distinguishing feature of pop fiction is its adherence to the genre formulas demanded by readers. The modern romance caters closely to popular tastes. Formulas are highly refined and targeted to specific audiences. For instance, the Rapture Romance series published by New American Library includes questionnaires in the back asking the readers what they liked or disliked about the book, and their socioeconomic status and age. With these data and sales figures, the editors establish "fiction factories" in which authors crank out endless versions of the same formulas with only minor variations.

The degree of creativity and innovation in pop fiction is greatly restricted by the formula approach and the work's values as an example of belles lettres is marginal. The importance of such works to the researcher is that, as escapist literature, they represent the longings and desires of a mass audience. The collective fantasies embodied in these works can be analyzed to determine "the mood of the people" at various times and locales.

\section{POPULAR CULTURE RESEARCH}

While the scholarly study of folklore and popular culture existed before the $1960 \mathrm{~s}$, the popular culture movement in American colleges and universities began in the social and intellectual ferment of that decade. The most significant developments in popular culture scholarship and teaching occurred at Bowling Green State University. In 1967, Ray B. Browne came to Bowling Green as professor of English. Subsequently, he established the Department of Popular Culture, the Center for the Study of Popular Culture, and the Popular Press, which began publishing the Journal of Popular Culture. Two years later, the Popular Culture Association (PCA) was founded and a newsletter was distributed.

Several significant scholarly monographs in popular culture studies were published in the early and mid-1970s. Russel Nye's The Unembarrassed Muse was published in $1970 .^{2}$ This was the first major, comprehensive scholarly work on the popular arts in America and is considered to be a watershed in the development of popular culture scholarship. In his 1974 book, Popular Culture and High Culture: An Analysis and Evaluation of Taste, Herbert Gans defends "popular culture against some of its attackers, particularly those claiming that only high culture is a culture, and that popular culture is a dangerous mass phenomenon. ${ }^{\prime \prime 3}$ This defensive attitude was quite common at the time among popular culture scholars, who met considerable resistance from their aca- 
demic colleagues. The acceptance problem has been exacerbated because traditional canons of taste and esthetics are not appropriate to the critical investigation of the popular arts. John Cavelti's 1976 book, Adventure, Mystery and Romance: Formula Stories as Art and Popular Culture, argues that new esthetic approaches are required when evaluating this type of material, approaches embracing the notions of formulas, genres, and archetypes. ${ }^{4}$

In addition to these major scholarly monographs, a flock of scholarly popular culture journals has emerged since the late 1960s. The first of these was Browne's Journal of Popular Culture. Others are Journal of Popular Film and Television, Journal of American Culture, Popular Culture Scholar, Popular Culture, Popular Music and Society, Clues: A Journal of Detection, and Journal of Cultural Geography. Most of these journals are published by the Bowling Green University Popular Press, which also publishes about ten new books each year devoted to popular culture. There are also other journals which occasionally publish articles about popular culture. To help sort some of this out, the Popular Press once published Abstract of Popular Culture, but unfortunately this publication has ceased.

\section{POPULAR CULTURE CURRICULA}

In conjunction with the growth of popular culture scholarship, there has also been an increase in the number of courses offered in popular culture studies. In Currents of Warm Life: Popular Culture in American Higher Education (1980), Mark Gordon and Jack Nachbar documented the nature and trends in popular culture curricula. ${ }^{5}$ Based on an extensive survey, they determined that 1,993 courses in popular culture studies were being taught at the 307 colleges and universities in the U.S. which reported. Follow-up checks of course bulletins and other estimates increased the total to between 12,000 and 20,000 courses. ${ }^{6}$ The number of new courses rose from 20 in 1968 to 134 in 1979 . The peak year was 1974 when 156 courses were taught for the first time.?

Gordon and Nachbar also reported that 258 courses were taught each year in pop- ular fiction with 14,939 enrollments. The subdivisions are:

$\begin{array}{lcc}\text { Subdivision } & \begin{array}{c}\text { No. of } \\ \text { Courses }\end{array} & \begin{array}{c}\text { No. of } \\ \text { Enrollments }\end{array} \\ \text { Detective fiction } & 39 & 1,934 \\ \text { Science fiction } & 85 & 5,387 \\ \text { Westerns and romances } & 41 & 3,143 \\ \text { Other popular fiction } & 93 & 4,475 \\ \text { TOTAL } & 258 & 14,939\end{array}$

The mean enrollment was no less than 48 . $^{8}$

The rapid rise of scholarship and teaching in popular culture during the 1970 s has leveled off but the demand for these courses is steady and strong. Moreover, forty percent of the survey respondents predicted an increase in the number of courses to be offered in the future. Fortysix percent believed that the number of courses would remain at present levels. Gordon and Nachbar concluded:

This survey clearly suggests that schools, programs, and departments sensitive to student demands and flexible about their future are already finding popular culture courses a valuable part of their offerings. Popular culture's struggles for life during its academic infancy are over. Teachers of popular culture may now look forward with confidence to the maturity of their subject matter as an important contributor to American higher education. ${ }^{9}$

\section{POPULAR CULTURE STUDIES AND LIBRARIES}

Characteristically, academic libraries have reacted slowly to changes in teaching and research trends. The reasons are complicated and varied but among the most important are the traditional axiom of collection development, "build on strength," and the lack of coordinated planning between academic departments and libraries. Academic libraries have refrained from collecting in the field of popular culture material and, as a result, library research and collecting have lagged behind the work of popular culture scholars and teachers. Nevertheless, the rapid rise and self-proclaimed mature status of popular culture studies have important implications for academic libraries.

Barbara Moran found a lack of:

Data on the number of libraries that have begun to systematically develop collections in popular culture but most estimates are that the number 
is disappointingly small. The major reason for this lack of response to a new field of study seems to be that popular culture brings an entirely new element to the academic library and most librarians have not accepted popular culture materials as appropriate for inclusion in the academic library.

Wayne Wiegand, an embattled advocate of popular culture collections, places the blame on the resistant attitudes in library schools and libraries:

Academic library collection development has an inertia of its own which is aided and abetted by the academic librarian's preconceived predilections, conservative training and book oriented practical experience. Add to this, tacit (if not conscious) support of an academically conservative, culturally elitist faculty on most campuses, and one can readily see the reasons why popular culture proponents receive little support from academic librarians in building collections of popular culture materials. ${ }^{11}$

The works of Moran and Wiegand appear in Twentieth-Century Popular Culture in Museums and Libraries. It is the first research monograph dealing with this aspect of librarianship. Few articles have appeared on the subject. Gordon Stevenson's "The Wayward Scholar: Resources and Research in Popular Culture" (1977) was one of the first. ${ }^{12}$ In contrast to the conclusions in Currents of Warm Life that popular culture's struggle for life is over, Stevenson and other advocates of popular culture collections in academic libraries realize that they are still on the defensive. ${ }^{13}$ They know, "What librarians have traditionally identified as 'trash,' 'entertainment,' and 'escape literature' are the basic resources of popular culture research. ${ }^{14}$ The debate on high culture versus low culture resources has still not been resolved. ${ }^{15}$

\section{POPULAR CULTURE AND LITERATURE COLLECTIONS}

Fred Schroeder has pointed out that "'by and large, it can be said that, historically, popular collections in research libraries are accidental and unwanted bequests of antiquarian scholars and monomaniac nostalgics. ${ }^{16}$ Whatever their origins, one can locate them in a variety of information sources. In the fifth edition of Ash's Sub- ject Collections (1978), one can find several relevant if inconsistent subject headings:

- Adventure and Adventures

- Comic Books, Strips, etc.

- Detective and Mystery Stories

- Dime Novels

- Fiction

- Fiction, Gothic

- Fiction, Western

- Pulp Magazines

- Science Fiction

One does not, however, find any heading under Popular Literature, Fiction, or Culture, even though there are "see references" for Popular Art, Popular Music, and Popular Periodicals.

The Directory of Special Libraries and Information Centers, 6th ed. (1981) indexes only three pertinent subject categories: Comics, Popular Culture, and Science Fiction. The most comprehensive list of popular culture collections appeared in the 1977 issue of the Popular Culture Association Newsletter under the title, "National Finding List of Popular Culture Holdings and Special Collections" compiled by Michael T. Marsden. ${ }^{17}$ Eighty libraries are listed in alphabetical order with details on the contents of their collections. Later issues of the newsletter contain descriptions of other collections. Elizabeth Cummins Cogell has also published an extensive descriptive listing of science fiction library holdings in The Science Fiction Reference Book. ${ }^{18}$

Within the realm of popular culture, pop fiction is probably the least troublesome to libraries since it appears in book or magazine format and can be easily cataloged and shelved, unlike collections of post cards, hubcaps, and match boxes. Pop fiction does, however, present many thorny issues. There is the fundamental problem of attitude and predilection: what is the relative value of pop fiction as opposed to "serious" literature? Even if this issue is resolved, there are technical and practical problems as well: Is there money and space for the tremendous volume of pop fiction which could be collected? How much effort and finances should be devoted to the preservation of mass market paperbacks and pulp magazines? 
In order to discover how academic and research libraries are dealing with these issues and to uncover the nature of established collections of pop fiction, a questionnaire was sent to a selected number of libraries. Telephone calls were made and further correspondence was conducted to amplify the questionnaire responses. The survey sought to ascertain why pop fiction is being collected, how the material is organized and cataloged, and what the collection development policies are in this area. Also surveyed were collection use, preservation problems, and future prospects.

Pop fiction materials are stored primarily in separate popular culture libraries or collections, as special collections within rare book or special collection divisions, and integrated into general literature collections. In the latter arrangement, materials are difficult to locate and describe since they are in a sense "lost" in the general stacks. The general stacks, however, are usually the largest repositories of pop fiction. Several profiles of important separate collections of pop fiction follow. These profiles demonstrate how libraries have consciously addressed the problems of collecting pop fiction.

\section{Popular Culture Library at Bowling Green State University}

The Popular Culture Library at Bowling Green State University was founded in 1969, two years after Ray Browne established the Center for Popular Culture and the Department of Popular Culture. The library's holdings include over 50,000 books, comic books, dime novels, Big Little Books, and paperback fiction plus more ephemeral items such as post cards, pennants, and greeting cards. The collection began with large donations to the English department. Some of the original pop literature collection contains "main stream" authors and the general collection has works of pop fiction. The popular culture librarian and the English librarian are now exchanging materials and insuring that the collections are housed properly.

All pop literature book material is cataloged and is represented in the main card catalog, a separate card catalog for the Popular Culture Library, and the auto- mated catalog. There is a sizable uncataloged backlog for which only minimal records exist. The pop fiction collection is integrated with other cataloged materials in the library.

The Popular Culture Library is one of the few academic libraries in the country which has a well-defined collection development statement for popular culture materials. In the area of pop fiction, the library collects in all areas of genre fiction with special emphasis on science fiction, as well as dime novels, pulp fiction magazines, and comics on a selective basis. The library comprehensively acquires works of certain authors, such as Ray Bradbury; certain publishers; and designated series, as well as award winners (e.g., Edgars and Nebulas), and Marvel and D.C. comics. The popular culture librarian believes the prospects are good for the expansion of the collection, partially because there is a large backlog on hand to be processed for the collection.

A source of some concern for the library is the almost exclusive reliance on donations for its pop fiction material and the drop off in the rate of donations. The materials budget for the Popular Culture Library is only five hundred dollars annually, and most of that goes to "support materials," such as indexes and reference works. The library may have difficulty fulfilling its mission with this meager budget. However, since the popular studies program and the collection at Bowling Green are well known, the library receives many gifts each year. Library use is increasing as the popular culture academic program expands and as researchers arrive at this mecca of popular culture studies.

\section{Nye Popular Culture Collection at Michigan State University}

The only other academic library with as strong a commitment as Bowling Green to its general popular culture collection is Michigan State University Library. The collection was established in 1968 and has been developed largely at the instigation and with the aid of Russel Nye, author of The Unembarrassed Muse and a pioneer in popular culture studies. This collection is in the Special Collection Division. 
The entire collection of popular fiction consists of over 35,000 volumes of which about 17,000 are comic books. Other components of the collection are juvenile literature and adult pop fiction. These areas cover materials from the mid-nineteenth century to the present and include over 400 dime novels with a nearly complete Deadwood Dick series from which University Microfilm International produced its film edition. There is a substantial representation of genre fiction: about 3,000 detective and mystery novels, approximately 1,750 volumes of science fiction, over 3,000 westerns (mostly published between 1900 and 1950), and over 2,500 romance novels, especially from the Harlequin series. There are also extensive holdings in pulp magazines, mainly for mysteries, westerns, and science fiction. A large vertical file is kept of science fiction "fanzines."

The current collection development policy mandates that only juvenile literature, such as Tom Swift and Nancy Drew stories, and comic books, particularly Marvel and D.C. publications, should be actively collected. There is no specific budget for pop fiction. It is purchased from the general special collections budget. The categories of romances, mysteries, and westerns are essentially in a passive state and are acquired through gift only, except when specified gaps in the pop fiction collections are identified and designated as target areas. The science fiction collection has continued to grow since the Michigan State University Library became a depository for the Science Fiction Writers of America in 1972.

The Nye Popular Culture Collection and other special collections at Michigan State have low priority for cataloging because these collections are noncirculating and the staff can locate every item in the collections. Within the Popular Culture Collection, the juvenile literature is cataloged first, and about half of that is fully cataloged. There are files of author cards made from acquisition records, and all uncataloged materials in popular fiction are shelved by genre and within genre by author.

The overall use of the collection is increasing each year. While student use has declined, use by scholars in the region has grown significantly. Although there is no specific program or department of popular culture at Michigan State, courses on popular culture that are taught in subjects such as English, sociology, and history use this collection as do researchers in various disciplines.

The special collections staff have produced two useful guides to the popular culture collections: The Russel B. Nye Popular Culture Collection ${ }^{19}$ and Finding Materials on American Popular Culture in the MSU Libraries. ${ }^{20}$ The former is a description of the collections and provides a brief history of each of the genres of pop fiction held in the collection. The latter is an excellent finding guide and reference manual that briefly describes the holdings and lists bibliographies, indexes, and reference materials for each category of pop fiction.

\section{San Francisco Academy of Comic Art}

One of the largest and most dynamic research collections of popular fiction is directly administered and not connected with any other academic institution. It is Bill Blackbeard's San Francisco Academy of Comic Art, a nonprofit research and study center. The academy and its library were founded in 1967 because of Blackbeard's personal conviction of the necessity to save the American printed comic strip at a time when most institutional libraries were destroying their bound newspaper files after purchasing microfilm editions. While the main emphasis of the academy is the comic strip, it provides a center for the unified study of all popular narrative arts.

The academy's library has holdings of at least one million comic strip tearsheets and pages, twenty-two thousand unbound periodicals, and approximately twelve thousand volumes of pop fiction. Blackbeard says the collection contains virtually all American comic strips from 1896; the most representative, extant collection of pulps; $;^{21}$ and a major research collection from 1800 to date of mystery/ crime fiction. In addition to collecting in all areas of genre fiction with the exception of the romance or "love story manque," the academy has collections of cinema adaptations and Hollywood/show business nov- 
els. Western fiction is accepted as donated but is rarely sought out. There are separate collections of Doyle/Sherlockia, Hammett/Chandler, Baum/Oziana, Alice in Wonderland, Dickens, Cruikshank, Gorey, and others.

A good deal of this material comes to the academy in the form of donations. But unlike the other collections discussed in this article, at least as much material is purchased as is received through gifts and exchange. There is no consistent materials budget; it all depends on what comes on the market and what Blackbeard can afford. All purchases are made from his personal funds, which he raises from his book royalties. A variety of sources and techniques are used to acquire materials. Besides solicitation of gifts and canny buying in bookstores and at auctions, Blackbeard frequents garage sales and trades duplicates and unwanted material with other libraries and collectors.

There is no catalog for the fiction collection but the books are arranged by genre and author so the user can immediately locate desired material and the staff is aware of all material in the collection. While there are no catalogs or bibliographies of the academy's holdings, one can locate material held in the collection by consulting standard reference works. For instance, the mystery/crime fiction collection contains virtually all titles listed in Ellery Queen's The Detective Short Story: A Bibliography, ${ }^{22}$ and the science fiction magazine file contains all titles in Donald Byrne Day's Index to the Science-Fiction Magazines, $1926-1950 .^{23}$

The library at the San Francisco Academy of Comic Art is open to the general public on an appointment basis, but fundamentally it is a research facility available to serious scholars. While the use of the library has, as a result, not been heavy, it has been significant. Since the academy opened in 1967, forty-seven books based on research from materials held in the library have been published, apart from the thirty-three edited by the academy itself. The prospects for the expansion of the popular fiction collection, let alone the comic strip collection, appear to be very good indeed, far better in fact than those in academic libraries. The personal commitment and savvy of the academy's director seem to assure its good fortune.

\section{Hess Collection at the University of Minnesota}

The Hess Collection, which is part of the Children's Literature Collections located in Walter Library at the University of Minnesota, is one of the oldest and largest collections of pop fiction in the country. ${ }^{24}$ It was established in 1954 when the library received a bequest of George Hess who collected dime novels as a hobby. The Hess Collection now contains seventy thousand dime and nickel novels published from 1860 to 1890 , approximately eight thousand children's series books, five hundred Big Little Books, and twelve hundred comic books. The novel collection contains almost complete sets of the various series of Beadle and Adams dime and nickel novels. It is such a comprehensive collection that University Microfilm International was able to base its microfilm edition almost entirely on the publications of Beadle and Adams in the Hess Collection.

One can locate many of the books in the Hess Collection by consulting Albert Johannsen's three volume bibliography, The House of Beadle and Adams and Its Dime and Nickel Novels. ${ }^{25}$ All of the dime and nickel novels have catalog cards for general series, and within those series there is a listing of authors and titles according to the numbered sequence, i.e., analytical cards. There are comprehensive lists citing title, author, and number for all Big Little Books held in the collection. A Department of Education Title II-C grant has provided cataloging for the Hess Collection and made it available on RLIN.

The use of the Hess Collection is reported to be increasing among students and faculty in American and English literature, American studies, and Library Science. There have been many articles and dissertations based on the research materials in the Hess Collection. ${ }^{26}$

\section{Library of Congress}

The Library of Congress is the largest storehouse of pop fiction in the country. 
This material is dispersed. Some of it is easy to locate in special collections, but most of it is not clearly designated and is integrated into general collections. The Rare Book and Special Collections Division has several collections of pop fiction described in Special Collections in the Library of Congress ${ }^{27}$ and The Rare Book Division; A Guide to Its Collections and Services. ${ }^{28}$ Some of the collections represented in these sources are the Armed Services Edition Collection (an archival set of paperbacks published for the American Armed Forces, 1943-47), The Big Little Book Collection, The Dell Paperback Collection (a virtually complete set from 1943), the Dime Novel Collection, and the Pulp Fiction Collection (popular American fiction magazines, 1920s-1950s). There are two published catalogs of special collections in the Rare Book and Special Collections Division: Children's Books in the Rare Book Division of the Library of Congress, ${ }^{29}$ and Cata$\log$ of Broadsides in the Rare Book Division. ${ }^{30}$ These written sources do not represent all the pop fiction materials held in this division. Many children's books, broadsides, and popular books of fiction concerning Abraham Lincoln are integrated into the Alfred Whital Stern Lincoln Collection.

There are, as well, many other locations of pop fiction materials in the Library of Congress. For instance, the Serial and Government Publications Division has a huge collection of comic books. The great bulk of pop fiction in the Library of Congress has been acquired through copyright deposit. Since 1870 , two copies of every copyrighted work have been sent to the Library of Congress. The vast majority of this has been cataloged and put into the general collections. While some of the works produced in today's fiction factories are not copyrighted, most are. If the scholar of pop fiction is looking for a particular work, it is most likely it will be found eventually somewhere in the vast holdings of the Library of Congress. ${ }^{31}$

\section{Other Libraries}

Pop fiction is scattered in collections all over the country. Some special collections are thriving because of strong research and study interest on campus; others may be donations that have not been developed or maintained. In the Special Collections Division at the University of Kansas Library there is a collection of over five thousand volumes of science fiction. Having held seminars and workshops on the genre in the past, the English department at Kansas has now established the first Center for the Study of Science Fiction in the country. The center's activities are under the direction of James Gunn and Stephen H. Goldman. In contrast, Kent State University Library established a special collection in 1967 of five hundred Armed Service Editions, a few hundred comic books, six hundred mystery and detective novels with special strengths in the works of Raymond Chandler and Stephen R. Donaldson, and some examples of dime novels. Most of the material was acquired through donations, but there is no plan to expand the collection.

Pop fiction is also found in general collections. Identifying the holdings and collection development practices in these cases is difficult and a vast undertaking, far beyond the scope of this paper. One can make, however, some tentative assessments and observations.

For members of the Research Libraries' Group there is some documentation on collection development patterns in pop fiction. The RLG Collection Development Manual $^{32}$ lists the levels of intensity of collection in specified subjects for all its member libraries. Under the category of Special Genres and Types of American and English Literature the following relevant subdivisions are given: Science Fiction, Westerns (Fiction), Detective and Mystery Stories, and Comic Books, Strips, etc. From these data, one discovers that the American Antiquarian Society collects science fiction on level four (comprehensive), Columbia University Libraries acquire detective and mystery stories on level four, and Colorado State University Library purchases western fiction on level four. The regional interest in western culture at Colorado State clearly justifies its collection patterns. But the reasons for the American Antiquarian Society's interest in science fiction and Columbia's in detective and mystery stories are not immedi- 
ately apparent, although the presence of that famous mystery fan, Jacques Barzun, on campus may have something to do with it.

Upon probing deeper into the situation, one discovers what the Antiquarian Society means by science fiction. The society acquires American printed materials issued before 1877 and places special emphasis on the popular manifestations of literature, religion, technology and science, and the arts. Within this context science fiction makes sense for the society.

At Columbia the circumstances are more puzzling the more one looks into them. In a letter dated October 25, 1982, the head of the reference department, Eugene Sheehy stated:

The Columbia University Libraries do not maintain a popular fiction collection as such, and it is not in an area in which we do systematic collecting. Some popular fiction does come into our collection via the various blanket order plans in which we participate, but this is the exception rather than the rule. Some older materials of that nature come to us by gift, but titles are added on a very selective basis in such cases.

This statement may seem at odds with the data in the RLG Collection Development Manual indicating that Columbia collects detective and mystery stories on a comprehensive level. I suspect, however, much the same might be said about the University of Illinois at UrbanaChampaign Library. Except for the H. G. Wells Collection, ${ }^{33}$ the library does not have a separate pop fiction collection and no mention of pop fiction is made in its acquisition policy statement. The library does have, however, large holdings of pop fiction of the formula variety. There are, for instance, numerous works of Robert Heinlein, Ray Bradbury, Dashiell Hammett, Agatha Christie, and Zane Grey, and nearly complete runs of Astounding Science Fiction (later Analog), Ellery Queen's Mystery Magazine, Galaxy, Magazine of Fantasy and Science Fiction, and the Omnibus of Crime series edited by Dorothy Sayer. Thus, with no explicit emphasis on pop fiction, this type of material was and is being collected.

The pop fiction which finds its way into academic libraries has not been collected exclusively or, perhaps not primarily, as research material. Much of it has been acquired for leisure reading for undergraduate libraries. When books lose their popularity, they are transferred to the main stacks. They become "research materials," as they grow older and become more scarce.

One observation that can be made about the authors of pop fiction collected by the library is that they exhibit some regard for traditional writing skills. For instance, the University of Illinois catalog has twentytwo entries for Dashiell Hammett but not a single one for Mickey Spillane. There is no question that Hammett is writer of greater talent than Spillane. But should not the library have some representation of the works of an author who has practically outsold the Bible?

This pattern of acquisition seems to hold for other libraries that collect pop fiction but do not specifically have a policy to do so. The better written, the more likely it is to be acquired. The romance genre, which is held in the lowest esteem because of its generally poor literary quality, is the least collected among the pop fiction genres. Science fiction, which is the least formularic in approach-its readers demand innovation and imagination-and is often written by mainstream novelists, is most collected. While detective stories and mysteries may have been and are being collected more for leisure reading, science fiction now seems to be thought of and acquired as research material. A recent special issue of Special Collection, Science/Fiction Collections: Fantasy, Supernatural $\mathcal{E}$ Weird Tales, ${ }^{34}$ offers some confirmation of this observation. The two most rapidly growing research collections of science fiction are the J. Lloyd Easton Collection at the University of California-Riverside ${ }^{35}$ and The Science Fiction Collection at Texas A \& M University. ${ }^{36}$ While these two collections are in the forefront, they are by no means alone in their specialized collecting endeavors.

\section{CONCLUSION}

Scholarly interest in popular culture and popular literature is widespread in America today. While to date only Bowling 
Green State University has a full-fledged department of Popular Culture, most U.S. colleges and universities offer courses in some aspect of popular culture. It is difficult to bring all of popular culture studies under one umbrella since the concept of popular culture is so broad and interdisciplinary. In a sense, it is defined by the kind of materials used for research and teaching-products of mass production made for quick and popular consumption. The implications for collection development and management are complex and demanding, and, to a large extent, not yet fully understood.

The academic library community is beginning to come to grips with some of the problems of popular culture collecting. A literature of popular culture librarianship is developing and some libraries collect relevant and appropriate resources. There is little systematic planning at a local, regional, or national level concerning popular culture and popular literature collecting. Most academic libraries rely heavily, if not exclusively, on donations for popular culture resources. The Popular Culture Library at Bowling Green has only a five hundred dollar annual budget and most of that goes for support material. The Library and Center for Popular Culture do, however, have active development programs for the solicitation of gifts. Many popular culture collections are essentially dead in that there is little or no actual or planned expansion. Among those libraries in the survey, the private and independent San Francisco Academy of Comic Art has the most active and innovative plan for the purchasing of popular culture and literature resources.

The bibliographic control of the collection surveyed seems to be primitive or totally lacking in most cases. Only the Popular Culture Library at Bowling Green has cataloged most of its holdings. For the time being, Michigan State University plans to catalog only its juvenile literature materials. One bright note in this area is that the Hess Collection at Minnesota is being fully cataloged and made available on RLIN, due to the federal grant received for this purpose. This action suggests that there is concern for bibliographic control and that some actual national planning is taking place. Many collections have files (not real catalogs) for series and authors. Where popular culture materials are organized as a separate entity and where good bibliographic control is lacking, popular literature collections are arranged by genre and authors. Librarians contend that this arrangement also provides relatively satisfactory access to the materials. In libraries in which pop fiction is not distinguished from other kinds of literature, full cataloging is the rule. But bibliographic control is still a major problem.

Because popular culture materials are products of mass production and often ephemeral in nature, preservation is an important problem. The mass market paperback and pulp magazine formats of most popular literature genres make preservation and conservation a universal problem for all libraries. A typical statement on preservation from the survey is: "Much of the material is in paperback and is printed on poor paper. It will not stand hard use. Some materials must be restricted to use by serious scholars." Some special collections such as Minnesota's Hess Collection, the Nye Collection at Michigan State, and collections of mysteries and children's books at Yale's Beineike Library are housed in temperature and humidity controlled environments. The San Francisco Academy of Comic Art presents a unique situation. Since the Academy is located near the sea with continual nonpolluted and lightly moist air circulation and a mean temperature of sixty to sixty-five degrees, the material is in a natural and ideal atmosphere and shows few signs of aging. In most libraries, however, pop fiction is unprotected and in various stages of deterioration. Perhaps the experimentation at the Library of Congress on the mass deacidification of books will help prolong the life of this material. At the New York Public Library, extensive microfilming is being done of pulp fiction materials. But first the books and magazines must be identified and selected for treatment. In many cases, it seems that preservation measures are only undertaken when popular culture materials become objects of nostalgia or 
are in danger of extinction. Early planning and preventative action would, of course, be easier and ideal. But all of this is a matter of priorities.

Academic and research libraries have diverse responsibilities and demands made upon them. Crucial decisions are being and will be made concerning what to collect and preserve of our cultural heritage. We may be in a situation where we must decide if an obscure literary magazine containing a fugitive poem of Ezra Pound should be preserved or if Astounding Science Fiction should get priority treatment. Should some library be acquiring the ten to twenty Harlequin novels being published monthly? These are controversial questions. Individual libraries will be making these decisions but there should also be regional and national planning by scholars and librarians as well. The Popular Culture Discussion Group of the American Library Association's Young Adult Services Division, the Popular Culture Association, the Research Resources Unit of the National Endowment for the Humanities' Research Division, and the Department of Education's Title II-C programs division are important forums for discussion of needs and priorities. In an academic world in which, along with Shakespearean scholars, there are scholars of Mickey Mouse and Agatha Christie, what may be regarded as today's trash could become a research treasure of tomorrow.

\section{REFERENCES AND NOTES}

1. Sixth Annual Meeting, April 22-24, 1976 (Bowling Green, Oh.: Popular Culture Association, 1976), p.2.

2. Russel Nye, The Unembarrassed Muse: The Popular Arts in America (New York: Dial, 1970).

3. Herbert J. Gans, Popular Culture and High Culture: An Analysis of and Evaluation of Taste (New York: Basic Books, 1974), p.vii.

4. John J. Cavelti, Adventure, Mystery, and Romance: Formula Stories as Art and Popular Culture, (Chicago: Univ. of Chicago, 1976).

5. Mark Gordon and Jack Nachbar, comps., Currents of Warm Life: Popular Culture in American Higher Education (Bowling Green, Oh.: Bowling Green Univ. Popular Pr., 1980). For another work discussing popular culture in secondary and higher education see: Ray B. Browne and Ronald J. Ambrosetti, eds., Popular Culture and Curricula, rev. ed. (Bowling Green, Oh.: Bowling Green Univ. Popular Pr., 1982).

6. Currents of Warm Life, p.32.

7. Ibid., p.40.

8. Ibid., p. 31 .

9. Ibid., p.48.

10. Barbara B. Moran, "Popular Culture and Its Challenge to the Academic Library," in Fred E. H. Schroeder, ed., Twentieth-Century Popular Culture in Museums and Libraries (Bowling Green, Oh.: Bowling Green Univ. Popular Pr., 1981), p.180-81.

11. Wayne A. Wiegand, "The Academic Library's Responsibility to Resource Needs of the Popular Culture Community," in Fred E. H. Schroeder, ed., Twentieth-Century Popular Culture in Museums and Libraries, (Bowling Green, Oh.: Bowling Green Univ. Popular Pr., 1981) p.195-96.

12. Gordon Stevenson, "The Wayward Scholar: Resources and Research in Popular Culture," Library Trends 25:779-818 (Apr. 1977).

13. For further readings in popular culture librarianship, see: Wayne Wiegand, "Popular Culture: A New Frontier for Academic Libraries," Journal of Academic Librarianship 5:200-204 (Sept. 1979); Wayne Wiegand, ed., Current Issues Symposium II: Popular Culture and the Library (Lexington: Office of Continuing Education, College of Library Science, University of Kentucky, 1978); Gordon Stevenson, "Popular Culture Studies and Library Education," Journal of Education for Librarianship 15:235-50 (Spring 1975); Jack A. Clarke, "Popular Culture in Libraries," College and Research Libraries 34:215-18 (May 1973); Barbara B. Moran, "The Popular Culture Collection Quandary: A Survey of Faculty Needs," Collection Building: 1:13-17 (Spring 1983).

14. Stevenson, "The Wayward Scholar," p.790.

15. The issue of high versus low culture has not only been raised in academic and research libraries. It is only recently that public libraries have begun to collect pop fiction in earnest. It has been thought 
that entertainment was the least important of the public library's mission, education being the first priority. For a patronizing view, but justification none the less, of the obligation of public libraries to collect pop fiction, see: Rudolph Bold, "Trash in the Library." Library Journal 105:1138-39 (May 15,1980 ).

16. Twentieth-Century Popular Culture, p.7.

17. Michael T. Marsden, "National Finding List of Popular Culture Holdings and Special Collections," Popular Culture Association Newsletter 6:5-29 (Mar. 1977).

18. Elizabeth Cummings Cogell, "Science Fiction and Fantasy Collections in U.S. and Canadian Libraries," in Marshall B. Tymm, ed., The Science Fiction Reference Book (Mercer Island, Wash.: Starmont House, 1981), p.378-452.

19. The Russel B. Nye Popular Culture Collection: A Descriptive Guide (East Lansing: Michigan State Univ. Libraries, 1978).

20. Finding Materials on American Popular Culture in the MSU Libraries (East Lansing: Michigan State Univ. Libraries, 1980).

21. The terms "pulp fiction" and "pulps" are used generically to refer to pop fiction in magazine format. The terms derive from the cheap (pulp) paper used in publishing pop fiction. For an informative discussion of both the physical characteristics and the literary aspects of pulps, see: Bill Blackbeard, "Pulps," in Thomas M. Inge, ed., Concise Histories of American Popular Culture (Westport, Conn.: Greenwood, 1982), p.189-307.

22. Ellery Queen, The Detective Short Story: A Bibliography (Boston: Little, 1942).

23. Donald Byrne Day, Index to the Science-Fiction Magazines (Portland, Oreg.: Perri Press, 1952).

24. For a description of some of the holdings in the Hess Collection, see: Austin McLean, Hess Collection: Dime Novels, Story Papers, Boy \& Girls Series Books, Paperbound Libraries (Minneapolis: Univ. of Minnesota Libraries Special Collections Department, 1974); Laura Quinn, Victorian Popular Fiction, (Minneapolis: Univ. of Minnesota Libraries Special Collections Department, 1974); Girls Series Books: A Checklist of Hard Back Books Published 1900-1975. (Minneapolis: Children's Literature Research Collections, Univ. of Minnesota Libraries, 1982).

25. Albert Johannsen, The House of Beadle and Adams and Its Dime and Nickel Novels: The Story of a Vanished Literature. 3 V. (Norman, Okla.: Univ. of Oklahoma, 1950-1962).

26. For example see: Patricia Mary Barnett, "English Boys' Weeklies, 1866-1899" (Ph.D. diss., Univ. of Minnesota, 1974); Donald Colberg, "Moral and Social Values in American Adventure Novels for Boys, 1886-1900" (Ph.D. diss., Univ. of Minnesota, 1973); Christian Messenger, "Sports in American Literature 1830-1930" (Ph.D. diss., Northwestern Univ., 1974).

27. Special Collections in the Library of Congress: A Selective Guide. comp. by Annette Meville. (Washington, D.C.: Library of Congress, 1980).

28. The Rare Book Division; A Guide to Its Collections and Services, rev. ed. (Washington, D.C.: Reference Department, Library of Congress, 1965).

29. Children's Books in the Rare Book Division of the Library of Congress (Totowa, N.J.: Rowman and Littlefield, 1975).

30. Catalog of Broadsides in the Rare Book Division. 4 v. (Boston: G. K. Hall, 1972).

31. For a description of the science fiction holdings at the Library of Congress with implications for pop fiction in general, see: Judith Mistichelli, "Science Fiction at the Library of Congress," Special Collections 2:9-24 (Fall/Winter 1982).

32. RLG Collection Development Manual. 2d ed. (Stanford, Calif.: Research Libraries Group, 1981).

33. For a description of the Wells Collection, see: Jean A. Major, comp., Collections Acquired by the University of Illinois Library at Urbana-Champaign 1897-1974, (Urbana, Ill.: Univ. of Illinois Library, 1974), (Robert B. Downs Publication Fund, no.2), p.53; for catalog of the collection, see: Univ. of Illinois Library Catalog of the Rare Book Room, v.11. (The Catalog of the Wells Collection) (Boston: G. K. Hall, 1972).

34. Special Collections 2 (Fall/Winter 1982).

35. George Slusser, "The J. Lloyd Eaton Collection," Special Collections 2:25-38 (Fall/Winter 1982).

36. Donald H. Dyal, "The Science Fiction Research Collection at Texas A \& M," Special Collections 2:39-48 (Fall/Winter 1982). 